\title{
Promising Peanut Lines in Northeastern Philippines
}

\author{
Jocelyn Aoalin Bernabe ${ }^{1}$ and Corazon C. Sugui ${ }^{2}$ \\ 1. College of Agriculture, Food \& Sustainable Development, Mariano Marcos State University, Dingras Campus 2913, Ilocos Norte, \\ Philippines
}

2. Crop Research Laboratory, Mariano Marcos State University, City of Batac 2906, Ilocos Norte, Philippines

\begin{abstract}
Peanut or ground nut (Arachis hypogea L.) is one of the food legumes with commercial importance in the Philippines grown by farmers (with small landholdings) in most parts of the country. However, one of the major constraints to peanut is the lack of supply of good stocks coupled with modern production technology. To alleviate this problem especially in those areas planted to this crop is the development of improved lines, their evaluation to different locations and their maintenance for sustained production. Thus, the project aimed to adapt, evaluate, select and identify high yielding, disease-resistant and other desirable characters of peanut in northeastern Philippines particularly at Mariano Marcos State University (MMSU), Dingras, Ilocos Norte, conducted from July 2014 to May 2015. The different lines of peanut were arranged in a randomized complete block design (RCBD) replicated four times. Optimum cultural requirements from planting to harvesting were followed to permit expressions of the genetic potential of the different lines of the crop. During wet and dry season trials, results revealed significant differences in all treatments relative to pod and seed yield, seed size, shelling percentage and plant height except number of pods per plant, and days to flower and mature. The lines ICGV 00337, ICGV 95111, and ICGV 98371 out yielded the remaining seven peanut lines registering a pod yield of 1,860 to $1,020 \mathrm{~kg} / \mathrm{ha}$ and had a yield advantage of $73 \%$ to $58.9 \%$, respectively over the check variety Ilocos Red. Growing peanut in northeastern Philippines can approximately give an income ranging from Php87,120 to Php93,960 per hectare with a benefit/cost ratio of 2.02 to 2.19 .
\end{abstract}

Key words: Commercial importance, food legumes, ground nut, promising lines.

\section{Introduction}

Developing countries in Asia, Africa, and South America account for over $97 \%$ of world peanut area and $95 \%$ of total production. The production is concentrated in Asia (50\% of global area and 64\% of global production) and Africa (46\% of global area and $28 \%$ of global production), where the crop is grown mostly by smallholder farmers under rainfed conditions. Globally, farmers tend about 24 million hectares of peanut each year, producing about 40 million metric tons (International Crops Research Institute for the Semi-Arid Tropics, 2014). According to United States Department of Agriculture (USDA), China leads in production of peanuts, having a share of about $42 \%$ of overall world production, followed

Corresponding author: Jocelyn Aoalin Bernabe, PhD in Agronomy, Associate Professor V, Research fields: legumes, vegetables, root crops and cereals.

Email: bernabejocelyn80@yahoo.com by India with $12 \%$ and the United States (8\%). In Southeast Asia, the top producing countries include Burma, Indonesia, Vietnam and Thailand. The peanut production in Vietnam slightly increased in 2012 from 469 TMT to 471 TMT in 2011 and is expected to increase in 2013 to about 10\%. The increase in peanut production may possibly be due to the favorable weather and variety improvement (USDA, 2012, 2013).

In the country, peanut is one of the food legumes with commercial importance that contributed much to domestic earnings. Though peanut is considered less important as a food crop in Papua New Guinea and Australia, it ranked among the top five crops generating income for the family and was reported as the top ranking cash crop (Rachaputi, 2006). However, in the Philippines, about 95\% of the peanut areas are planted with the low yielding "native" Spanish type variety (Department of Agriculture-Regional Field 
Unit 6, n.d.). Low yields of peanut are mainly attributed to lack of high-yielding adaptive cultivars, damaged by diseases and pests, poor agronomic practices, unreliable rainfall patterns with frequent droughts, and limited use of inputs (Sharma \& Bhatnagar, 2006).

The traditional variety is the popular variety being used by farmers due to unavailability of improved varieties in the provinces (Huelgas, 1990). To improve the peanut production, international breeding programs such as USDA and International Crops Research Institute for Semi-Arid Tropics (ICRISAT, n.d.) are developing cultivars that are high yielding with desirable characteristics such as large seed size, early maturing and tolerant to foliar diseases and acidic soils (University of Florida, n.d.).

Varietal trials conducted at Aiyura, Keravat and Ramu Sugar showed that some of the new introductions from ICRISAT have out-yielded local checks by 2-3 times at all locations. Verification trials have also resulted in the identification of promising peanut varieties with potential to yield $50-100 \%$ greater than the local check varieties (ACIAR, 2001). It is estimated that improved peanut varieties currently occupy more than $60 \%$ of the total area for peanut production in Malawi due to significant yield advantage over local checks (ICRISAT, n.d.).

New peanut varieties are released and introduced every year to evaluate their yield potential. Asha peanut variety was introduced and promoted by ICRISAT in 2005 to address farmers' continuous demand for new and much better variety. Results from national cooperative trials (NCT) showed that Asha consistently ranked number one in yield surpassing the National Seed Industry Council (NSIC) Pn 11 by $22 \%$ and $10 \%$ during wet and dry seasons. Asha is the only variety released in the Philippines that produced the highest recorded yield of 3.99 tons/ha (Bureau of Agricultural Research, 2010).

Despite the abundance of released improved varieties, only a few are best adapted for production. It is believed that peanut varieties differ in their agronomic characteristics and yield potential due to different agro-climatic adaption because varietal response in terms of productivity is largely determined by soil factor, climatic conditions and cultural practices.

The Field Legumes Technical Working (Varietal Improvement) Group (FLTWG) of the NSIC through the National Cooperative Testing (NCT) Project is a collaborative research endeavor jointly implemented by different government agencies like IPB-UPLB, DA-NCRDC, DA-RFU and ARC and selected State Colleges and Universities (SCU's). The Institute of Plant Breeding at University of the Philippines Los Bañosis is the lead agency and the Mariano Marcos State University (MMSU) is one of the selected testing sites in Region I.

Specifically, the study conducts field testing of new promising lines of legumes to generate adequate and reliable basic information as basis for variety recommendation. Our country is still importing peanut due to lack of supply or due to scarcity being experienced during the lean months, hence, it commands a high price. For this reason, successful production of peanut resulting to high yielding of the crop depends greatly on the genetic make-up of the varieties used under specific locations and conditions. Thus, peanut yields must be improved through breeding or varietal improvement coupled with appropriate recommended production technology so as to increase production. The study aimed to evaluate and select promising entries of peanut that are high yielding, disease resistant and acceptable to the farmers; identify promising entries and to get conclusive results and as a basis for recommendation to the NSIC as national, regional or local variety under specific conditions; and, improve the yield and other characteristics of peanut suited to our local conditions.

\section{Methodology}

Regional variety trials for peanut were conducted 
during the wet season from July to November 2014 and dry season from December, 2014 to May 2015 at the MMSU, Dingras Research Farm. Entries were set employing the randomized complete block design (RCBD) with four replications.

Peanut lines were planted in a 2-meter row plot spaced $50 \mathrm{~cm}$ and 5 meters long. The seeds per entry were drilled uniformly in the furrows and thinned out maintaining 15 to 20 plants per linear meter, 11/2 weeks after planting. Complete (14-14-14) fertilizer was applied at planting time at the rate of $30 \mathrm{~kg} \cdot \mathrm{ha}^{-1}$ of $\mathrm{N}_{2} \mathrm{P}_{2} \mathrm{O}_{5}$ and $\mathrm{K}_{2} \mathrm{O}$. Hilling-up was done 35 days after emergence (DAE) followed by spot weeding. Irrigation was done three times during the dry season trial and once during the rainy season trial.

The crops were sprayed with insecticides to control the attack of insect pests and diseases just after taking the rating. Peanut was harvested when the foliage turned yellow green or when about $75 \%$ of the pods have deep ridges, when the inner side of the shell shows oily streaks or dark venations and when the seeds are plump and compact within the shell. The peanut pods were separated from the plants manually so that the matured pods were taken only. The harvested pods were dried for three consecutive days prior to shelling and threshing. Manual shelling and threshing of the pods were done to avoid damages to the seeds and mixtures from one another. Gathering of data and observations were taken from the two inner rows of the plot.

\subsection{Parameters Taken}

Days to flower: this was recorded as the number of days from emergence to that day when $50 \%$ of the plants in a row have produced their first open flower.

Days to maturity: this was recorded as the number of days from emergence to such time when at least $75 \%$ of the pods in a plot show signs of maturity (dark brown pods with deep ridges) for peanut.

Number of pods per plant: this was determined by computing the average number of pods per plant at harvest using the 10 sample plants used for height determination.

Number of seeds per pod: this was determined by counting the number of seeds per pod from the 10 sample pods and computing the average.

Weight of 100 seeds (g): 100 seeds at random from each treatment were counted and recorded the weight in grams.

Shelling percentage: this was obtained by weighing the shelled seeds from the 100 gram pod sample from each plot.

Plant height: this was determined by measuring 10 sample plants from the harvest area.

Pod yield (tons/ha): the pod yield was taken from the two inner rows (harvest area) of the plot weighed and recorded.

\section{Results and Discussion}

\subsection{Pod Yield}

Ten lines together with the check variety (Ilocos Red) were evaluated within two cropping seasons, the wet and dry. Result of the series of experiment shows significant differences among entries. The pod yield of peanut entries per hectare showed a significant difference from each other (Table 1). During the wet season trial, line ICGV 95111 produced the highest pod yield of 1,126.5 kg.ha ${ }^{-1}$ but the yield obtained was comparable to entries ICGV 98371 with a pod yield of $1,020 \mathrm{~kg} \cdot \mathrm{ha}^{-1}$. During the dry season cropping, ICGV 00337 registered the highest pod yield of 1,860 kg.ha ${ }^{-1}$ followed by ICGV 98371 with 1,125 $\mathrm{kg} \cdot \mathrm{ha}^{-1}$. On the average pod yield, ICGV 00337 registered the highest yield with $1,305 \mathrm{~kg} \cdot \mathrm{ha}^{-1}$.

\subsection{Seed Yield}

As to the seed yield produced, the same trend was observed in the production of seeds per hectare both in wet and dry season cropping as shown in Table 1 . ICGV 95111 produced the highest seed yield of 813.3 $\mathrm{kg} \cdot \mathrm{ha}^{-1}$ but was comparable to line ICGV 98371 with a yield of $784.4 \mathrm{~kg} \cdot \mathrm{ha}^{-1}$. During the dry season 
cropping ICGV 00337 produced the highest seed yield of $1,140 \mathrm{~kg} \cdot \mathrm{ha}^{-1}$ and this variety also registered the highest mean seed yield of $841.5 \mathrm{~kg} \cdot \mathrm{ha}^{-1}$. Lines ICGV 00337, ICGV 98371 and ICGV 95111 showed a seed yield advantage of $73.6 \%, 59.6 \%$ and $58.9 \%$ over the check variety Ilocos Red.

\subsection{Yield Components}

The weight of 100 seeds of the peanut lines showed a significant difference from each other both in wet and dry season cropping (Table 2). During the wet season, ICGV 95111 produced the biggest seeds with $44.6 \mathrm{~g} / 100$ seed weight but was comparable to line ICGV 00308 with 40.4 g/100 seed weight. All other entries had smaller seeds including the check variety. During the dry season trial, same trend was observed; the two lines gave the highest seed yield of $71.0 \mathrm{~g}$ and 62.8 g per 100 seed weight, respectively.

The number of pods per plant and number of seeds per pod did not vary significantly from each other both in wet and dry season cropping. The number of pods per plant ranged from 8.1 to 16.1 pod per plant during wet season trial and 13.1 to 22.7 pods per plant during the dry season cropping. As regards to the number of seeds per pod, all entries including the check variety produced 1.4 to 1.8 seeds per pod during wet season trial and 1.8 to 2.3 seeds per pod during the dry season cropping. Moreover, all entries produced good quality seeds both in wet and dry season trial so they were rated 1.0.

\subsection{Agronomic Characteristics}

Shelling percentage of the different lines tested showed significant results during the wet and dry season trials. During the wet season trial, ICGV 91114 had the highest shelling outturn of $80.0 \%$ but was comparable to ICGV 98371 and ICGV 95069 with $76.9 \%$ and $76.0 \%$ shelling outturn, respectively. During the dry season trial, ICGV 00308 produced the highest shelling outturn of $75.7 \%$.

The height of plants differed significantly among entries tested. During the wet season trial, ICGV 00308 significantly produced taller plants with 75.0 $\mathrm{cm}$ but was comparable to the check variety Ilocos Red. Shorter plants were observed during the dry season cropping and line ICGV 98371 produced the tallest with $60.3 \mathrm{~cm}$ in height.

There was no significant difference observed in the flowering and maturity of the peanut plants both in wet and dry season cropping. All the peanut entries

Table 1 Yield of peanut lines against the check variety grown under MMSU condition during 2014 wet season and 2014-2015 dry season cropping.

\begin{tabular}{|c|c|c|c|c|c|c|c|}
\hline \multirow{2}{*}{ ENTRY } & \multicolumn{2}{|c|}{ Pod yield $\left(\mathrm{kg} \cdot \mathrm{ha}^{-1}\right)$} & \multirow{2}{*}{$\begin{array}{l}\text { Mean pod } \\
\text { yield (kg) }\end{array}$} & \multicolumn{2}{|c|}{ Seed yield $\left(\mathrm{kg} \cdot \mathrm{ha}^{-1}\right)$} & \multirow{2}{*}{$\begin{array}{l}\text { Mean seed } \\
\text { yield }\end{array}$} & \multirow{2}{*}{$\begin{array}{l}\text { \% yield advantage } \\
\text { over Ilocos Red }\end{array}$} \\
\hline & WS & DS & & WS & DS & & \\
\hline ICGV 00308 & $616.5^{c}$ & $965.0^{\mathrm{d}}$ & 790.8 & $461.9^{c}$ & $736.0^{b}$ & 598.9 & 23.5 \\
\hline ICGV 00337 & $750.0^{\mathrm{b}}$ & $1,860.0^{\mathrm{a}}$ & $1,305.0$ & $543.0^{\mathrm{b}}$ & $1,140.0^{\mathrm{a}}$ & 841.5 & 73.6 \\
\hline ICGV 02022 & $630.0^{c}$ & $785.0^{\mathrm{e}}$ & 707.5 & $453.1^{c}$ & $562.5^{\mathrm{c}}$ & 507.8 & 4.8 \\
\hline ICGV 91114 & $215.0^{\mathrm{e}}$ & $1,095.0^{\mathrm{C}}$ & 655.0 & $168.1^{\mathrm{e}}$ & $781.5^{\mathrm{b}}$ & 474.8 & -2.1 \\
\hline ICGV 95066 & $516.5^{\mathrm{d}}$ & $1,095.0^{\mathrm{C}}$ & 805.8 & $346.2^{\mathrm{d}}$ & $764.5^{\mathrm{b}}$ & 555.4 & 14.6 \\
\hline ICGV 95069 & $543.5^{\mathrm{d}}$ & $1,055.0^{\mathrm{C}}$ & 799.3 & $413.0^{c}$ & $757.5^{\mathrm{b}}$ & 585.3 & 20.7 \\
\hline ICGV 95111 & $1126.5^{\mathrm{a}}$ & $1,020.5^{\mathrm{c}}$ & $1,073.5$ & $813.3^{\mathrm{a}}$ & $728.0^{\mathrm{b}}$ & 770.7 & 58.9 \\
\hline ICGV 98371 & $1020.0^{\mathrm{a}}$ & $1,125.0^{\mathrm{b}}$ & $1,072.5$ & $784.4^{\mathrm{a}}$ & $762.5^{\mathrm{b}}$ & 773.5 & 59.6 \\
\hline ICGV 99195 & $606.5^{c}$ & $645.0^{\mathrm{e}}$ & 625.8 & $447.2^{\mathrm{c}}$ & $458.0^{c}$ & 452.6 & -6.6 \\
\hline Ilocos Red (ck) & $546.5^{\mathrm{d}}$ & $925.0^{\mathrm{d}}$ & 735.8 & $371.5^{\mathrm{d}}$ & $598.0^{\mathrm{c}}$ & 484.8 & \\
\hline Mean & 897.1 & $1,057.0$ & & 654.7 & 728.9 & & \\
\hline CV \% & 11.8 & 7.7 & & 10.0 & 11.3 & & \\
\hline Significance & $* *$ & $* *$ & & $* *$ & $* *$ & & \\
\hline
\end{tabular}

Means having the same letter in a column are not significantly different at 1\% level using Honestly Significant Difference Test (HSD). 
Table 2 Yield components of peanut lines against the check variety grown under MMSU condition during 2014 wet season and 2014-2015 dry season cropping.

\begin{tabular}{llllllll}
\hline \multirow{2}{*}{ ENTRY } & \multicolumn{2}{c}{ 100 Seed weight (g) } & \multicolumn{2}{c}{ Pods per plant } & \multicolumn{2}{c}{ Seeds per pod } & Seed quality \\
\cline { 2 - 8 } & WS & DS & WS & DS & WS & DS & 1 \\
\hline ICGV 00308 & $40.4^{\mathrm{ab}}$ & $62.8^{\mathrm{b}}$ & 10.9 & 16.4 & 1.4 & 1.8 & 1 \\
ICGV 00337 & $26.4^{\mathrm{c}}$ & $55.4^{\mathrm{c}}$ & 11.3 & 13.1 & 1.7 & 2.0 & 1 \\
ICGV 02022 & $25.9^{\mathrm{c}}$ & $52.5^{\mathrm{c}}$ & 12.4 & 16.5 & 1.6 & 2.1 & 1 \\
ICGV 91114 & $35.6^{\mathrm{bc}}$ & $59.7^{\mathrm{bc}}$ & 8.9 & 14.6 & 1.6 & 1.9 & 1 \\
ICGV 95066 & $30.2^{\mathrm{c}}$ & $55.7^{\mathrm{c}}$ & 10.7 & 17.1 & 1.7 & 1.9 & 1 \\
ICGV 95069 & $28.1^{\mathrm{c}}$ & $54.2^{\mathrm{c}}$ & 12.1 & 14.9 & 1.6 & 2.0 & 1 \\
ICGV 95111 & $44.6^{\mathrm{a}}$ & $71.0^{\mathrm{a}}$ & 16.6 & 21.8 & 1.7 & 2.0 & 1 \\
ICGV 98371 & $37.6^{\mathrm{b}}$ & $56.0^{\mathrm{c}}$ & 13.3 & 22.7 & 1.7 & 2.0 & 1 \\
ICGV 99195 & $33.5^{\mathrm{bc}}$ & $47.7^{\mathrm{d}}$ & 8.1 & 16.1 & 1.6 & 1.8 & 1 \\
Ilocos Red (ck) & $26.7^{\mathrm{c}}$ & $41.1^{\mathrm{e}}$ & 8.2 & 14.8 & 1.8 & 2.3 & 1.7 \\
Mean & 32.9 & 55.6 & 11.3 & 16.8 & 1.7 & 2.0 & $\mathrm{n}$ \\
CV \% & 7.3 & 4.6 & 11.2 & 6.7 & 6.2 & 8.3 & $\mathrm{~ns}$ \\
Significance & $* *$ & $* *$ & $\mathrm{~ns}$ & $\mathrm{~ns}$ & $\mathrm{~ns}$ & \\
\hline
\end{tabular}

Means having the same letter in a column are not significantly different at $1 \%$ level using HSD.

Table 3 Agronomic characteristics of peanut lines against the check variety (Ilocos Red) grown at MMSU condition during the 2014 wet season and 2014-2015 dry season cropping.

\begin{tabular}{|c|c|c|c|c|c|c|c|c|c|}
\hline \multirow{2}{*}{ ENTRY } & \multicolumn{2}{|c|}{ Shelling \% } & \multicolumn{2}{|c|}{ Plant height $(\mathrm{cm})$} & \multicolumn{2}{|c|}{ Days to flower (DAE) } & \multicolumn{2}{|c|}{ Days to mature (DAE) } & \multirow{2}{*}{-Seed color } \\
\hline & WS & DS & WS & DS & WS & DS & WS & DS & \\
\hline ICGV 00308 & $74.6^{\mathrm{b}}$ & $75.7^{\mathrm{a}}$ & $75.0^{\mathrm{a}}$ & $50.8^{\mathrm{bc}}$ & 40.0 & 42.0 & 119.0 & 120.0 & Pink \\
\hline ICGV 00337 & $72.1^{\mathrm{b}}$ & $62.0^{c}$ & $53.6^{\mathrm{c}}$ & $55.6^{\mathrm{b}}$ & 38.3 & 41.0 & 117.3 & 119.0 & Pink \\
\hline ICGV 02022 & $71.9^{c}$ & $64.7^{\mathrm{c}}$ & $64.3^{\mathrm{b}}$ & $54.3^{\mathrm{b}}$ & 40.8 & 46.0 & 119.8 & 124.0 & Pink \\
\hline ICGV 91114 & $80.0^{\mathrm{a}}$ & $71.0^{\mathrm{b}}$ & $60.3^{\mathrm{bc}}$ & $55.6^{\mathrm{b}}$ & 42.3 & 41.8 & 121.3 & 119.8 & Tan \\
\hline ICGV 95066 & $66.9^{c}$ & $70.3^{b}$ & $56.2^{\mathrm{C}}$ & $56.8^{\mathrm{b}}$ & 39.8 & 38.3 & 118.8 & 116.3 & Tan \\
\hline ICGV 95069 & $76.0^{\mathrm{ab}}$ & $71.9^{\mathrm{b}}$ & $64.1^{\mathrm{b}}$ & $51.1^{\mathrm{bc}}$ & 40.3 & 38.0 & 119.3 & 116.0 & Tan \\
\hline ICGV 95111 & $72.2^{\mathrm{b}}$ & $71.0^{\mathrm{b}}$ & $61.5^{\mathrm{b}}$ & $47.4^{\mathrm{c}}$ & 40.3 & 43.0 & 119.3 & 121.0 & Red \\
\hline ICGV 98371 & $76.9^{\mathrm{ab}}$ & $68.1^{\mathrm{bc}}$ & $54.7^{\mathrm{c}}$ & $60.3^{\mathrm{a}}$ & 39.3 & 42.3 & 118.3 & 120.3 & Red \\
\hline ICGV 99195 & $73.6^{\mathrm{b}}$ & $69.5^{\mathrm{bc}}$ & $55.4^{\mathrm{c}}$ & $50.1^{\mathrm{bc}}$ & 37.0 & 44.8 & 116.0 & 123.8 & Pink \\
\hline Ilocos Red (ck) & $68.0^{\mathrm{C}}$ & $65.3^{c}$ & $71.6^{\mathrm{a}}$ & $43.8^{\mathrm{c}}$ & 36.0 & 41.3 & 115.0 & 119.3 & Red \\
\hline Mean & 73.3 & 68.9 & 61.7 & 52.6 & 39.4 & 41.8 & 118.4 & 119.9 & \\
\hline $\mathrm{CV} \%$ & 5.0 & 7.6 & 14.2 & 7.3 & 4.7 & 2.3 & 1.5 & 0.6 & \\
\hline Significance & $* *$ & $* *$ & $* *$ & $* *$ & ns & ns & ns & ns & \\
\hline
\end{tabular}

Means having the same letter in a column are not significantly different at $1 \%$ level using HSD.

flowered 36 to 40 DAE during wet season and 38 to 46 DAE during dry season. On the other hand, the entries matured about 115 to 121 DAE both in wet and dry season trials.

\section{Conclusion}

Findings revealed significant differences in all treatment means during wet and dry seasons in terms of pod yield and seed yield $\left(\mathrm{kg} \cdot \mathrm{ha}^{-1}\right)$, weight of 100 seeds, shelling percentage and plant height. The line
ICGV 00337, ICGV 95111, and ICGV 98371 surpassed the remaining seven peanut varieties registering a pod yield of 1,860 to 1,020 and had a yield advantage of 58.9 to $73.6 \%$, respectively over the check variety Ilocos Red. These lines also produced the biggest seeds.

The results of the study would provide awareness to marginal farmers, peanut growers and other stakeholders especially in the northeastern Philippines, on the available promising peanut lines that can be 
grown during either or both wet and dry season. Through the NCT and the NSIC, promising lines of peanut are evaluated based on the distinct agronomic characteristics, resistance to major diseases including its optimum yield.

Based on the results, the three promising lines ICGV 00337, ICGV 95111, and ICGV 98371 are recommended to farmers. The use of these promising lines will improve peanut production, increase farmers' profit that will eventually help the peanut industry as a whole. Finally, these lines are already recommended for varietal release and considered by the NSIC.

\section{Acknowledgement}

The researchers would like to thank the Research Directorate of Mariano Marcos State University for supporting the conduct of this research and to everybody who shared his/her valuable time for the successful implementation. The National Seed Industry Council-Field Legumes Technical Working Group (NSIC-FLTWG) for the necessary data gathered from the different growing areas in Philippines to show the validity of the results.

\section{References}

[1] Australian Centre for International Agricultural Research (ACIAR). 2001. "Improving Yield and Economic Viability of Peanut Production in Papua New Guinea and Australia Using Integrated Management and Modelling Approaches." http://aciar.gov.au/project/asem/2001/055.

[2] Bureau of Agricultural Research. 2010. "Asha Peanut Is Now NSIC Approved.” 11 (2). http://www:bar.gov.ph/chronicle-home/archives-list/71-ju.
[3] Bureau of Agricultural Research. 2011. "2 Promising Peanut Lines Recommended for NCT Trials.” http://www.bar.gov.ph/press-room/newsand-events/650-2 011-07-icrisat.

[4] Department of Agriculture-Regional Field Unit (DA-RFU 6). n.d. "Undated. Agribusiness-Peanut." http://rfu6.da.gov.ph/agribiz/peanut.htm.

[5] Gatan, M. G. B., and Gonzales, V. D. 2014. "On-Farm Verification of Peanut Varieties in Rainfed and Lahar Laden Areas of Pampanga, Philippines.” JPAIR Multidisciplinary Research 18 (1).

[6] Huelgas, R. R., Manuel, P. C., and Gabriel, E. S. 1990. Socioeconomic study on Peanut Production in the Philippines. Philippine Council for Agriculture, Forestry and Natural Resources Research and Development. DOST. Book Series No. 90/1990.Los Baños, Laguna, Philippines.

[7] International Crops Research Institute for Semi-Arid Tropics. 2015. "Undated. Groundnut (Arachis hypogaea L.)." http://www.icrisat.org/ crop-groundnut.htm.

[8] Rachaputi, R. C. 2006. Improving Yield and Economic Viability of Peanut Production in Papua New Guinea and Australia Using Integrated Management and Modelling Approaches-Overview of ACIAR Project ASEM 2001/055. Improving yield and economic viability of peanut production in Papua New Guinea and Australia.

[9] Saese, H., Fahey, G., and Bafui, J. 2006. "Evaluation of Peanut (Arachis hypogaea L.) Varieties in the Lower Markham Valley of Papua New Guinea. Improving Yield and Economic Viability of Peanut Production in Papua New Guinea and Australia.” In P. Peanut (Arachis hypogaea L.) In Agrobacterium Protocols, edited by Sharma, K. K., and Bhatnagar-Mathur, Humana Press, pp. 347-58.

[10] United States Department of Agriculture (USDA). 2012. Foreign Agricultural Service. Created on March 10, 2015. http://apps.fas.usda.gov/psdonline/psdreport.aspx?hidRep ortRetrievalName=BVS\&hidReportRetrievalID=918\&hi dReportRetrievalTemplateID=1\#ancor. 